\title{
Ond optimisme \\ og viljen til lykke
}

Af Sanne Frłer Andersen

Det liberale dogme 'enbver er sin egen lykkes smed'er tilbage med fornyet relevans. Neoliberal ideologi har $i$ mange vestlige demokratier bevirket en afpolitisering af samfundsmassige forbold, en afpolitisering som gair baind $i$ haind med psykologiseringen af stadigt fleve kollektive domaner. Dette forbold kalder på en gentankning af folelsers betydning og det feministiske credo 'det private er politisk'.

E S S A Y

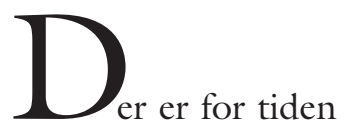

en bred interesse for følelser og affekt $\mathrm{i}$ academia (Gregg \& Seigworth (red): The Affect Theory Reader (2010), Clough \& Halley (red): The Affective Turn (2007), Liljeström \& Paasonen (red): Working with Affects in Feminist Readings (2010). Denne interesse samler sig ikke omkring en bestemt skole eller videnskabelig tradition, men er snarere en mangfoldighed af disciplinære endsige postdisciplinære vinkler som anskuer temaet, eller konstituerer analyseobjektet, fra divergerende positioner og med forskellige nomenklaturer. Følelser og affekt er et varmt emne inden for blandt andet sociologi, historie og psykologi såvel som i robotteknologi, neuroscience, kybernektik og bioinformatik. Feltet er således stærkt differentieret og samtidig kendetegnet ved erkendelsesmæssige og metodiske overlap. Interessen for følelser og affekt forklares ofte som en reaktion på den lingvisme, der siges at følge med de poststrukturalistiske, dekonstruktive og konstruktivi- 
stiske linjer, som har præget ikke bare humaniora, men også natur-, medicin- og statskundskaberne gennem de seneste 3-4 årtier. Således tegnes konturerne af en affektiv vending som først og fremmest er en vending fra epistemologi til ontologi, fra tekst til krop. Interessen for følelser og affekt er dog ikke nødvendigvis erklæret ontologisk eller interesseret i mennesket. Og der hvor interessen for følelser og affekt er mest menneskelig, afviger den nogen gange så meget fra de institutionelle forskningstraditioner at den kan kaldes postteoretisk. Eller endda terapeutisk. ${ }^{1}$

Køns- og postkoloniale studier har en historisk særinteresse $\mathrm{i}$ og tradition for at arbejde med følelser og affekt. Følelser er fornuftens anden, og i de vestlige vidensinstitutioner har forskellige former for rationalisme og empirisme udgrænset fx retorik og religion reciprokt med udgrænsningen af følelserne og det kvindelige. ${ }^{2}$ Feministiske og postkoloniale studier har vist, hvordan den filosofiske tradition har været, og stadig er, bundet af et kønnet og racialiseret krop/sind-hierarki med hvilket følelser konstitueres gensidigt med det irrationelle, det fysiske, det naturlige, det partikulære, det private, den sorte og kvinden (Koivunen 2010: 10).

\section{SARA AHMED OG \\ LAUREN BERLANT- EN INTRO}

Jeg beskæftiger mig i dette essay med to væsentlige eksponenter for, hvad man har kaldt Den affektive vending i queer- og postkoloniale studier, nemlig Sara Ahmed og Lauren Berlant. ${ }^{3}$ Hensigten med essayet er todelt. For det første ønsker jeg at introducere til Sara Ahmeds greb om følelser og affekt som det udfolder sig i bogen The Cultural Politics of Emotion. I stedet for at placere følelser og trivsel i fx det private eller i psykologien, giver Ahmed en indsigt i, hvordan følelser former politik, nationalitet og andre kollektive koreografier. Hendes perspektiv står i stærk kontrast til den oven- nævnte neoliberale individkultur - og taler for et kollektivt forandringsarbejde. I essayets anden del giver jeg to eksempler på, hvordan og hvorfor kønsforskningen forholder sig til den kulturelle økonomi, vi kalder 'det gode liv.' Jeg skitserer en række lykkekritiske pointer fra Ahmeds The Promise of Happiness og runder essayet af med en anbefaling af Berlants Cruel Optimism. Både Ahmed og Berlant analyserer og dekonstruerer de følelsesmæssige strukturer og regulativer som (per)former/reproducerer normer for glæde, succes, håb, det gode liv, det efterstræbelsesværdige, lykken osv. Essayet vil både på og mellem linjerne indeholde spor af terapi, tydeligst med introduktionen til Ahmeds feministiske figur 'Den feministiske Glædesdræber'.

Sara Ahmed beklæder et professorat i Race and Cultural Studies ved Department of Media and Communications, Goldsmith. Hun undersøger, hvordan kroppe, objekter og verdener folder sig ud og tager form i mødet med andre. Hvordan magt sikres og udfordres i hverdagslivets differerende formationer, i institutionelle kulturer og i produktionen af national identitet. I bøgerne The Cultural Politics of Emotion (2004) og The Promise of Happiness (2010) er Ahmed særligt interesseret i, hvordan specifikke grupper, individer og kroppe konstitueres, privilegeres, underordnes eller udgrænses omkring sociale akser af gode/dårlige følelser.

Lauren Berlant er George M. Pullman, Professor i engelsk ved University of Chicago. Gennem de seneste tyve år har hun interesseret sig for offentlige følelser, affektive medborgerskaber og for, hvad hun samlende kalder national sentimentalitet. Hun interesserer sig for, hvordan den intime offentlighed fungerer $\mathrm{i}$ affinitet til normative kærlighedsmodi og til loven. Derudover er hun medstifter af Feel Tank Chicago, en føletank bestående af akademikere såvel som af kunstnere og aktivister. Feel Tank Chicago har arrangeret depressionsdemonstrationer og følelseskonferencer. På deres mer- 
chandise står der "Depressed? - It might be political". I bogen Cruel Optimism (2011) giver Berlant en bred karakteristik af et historisk nu, som hun blandt andet beskriver med udtrykket 'det neoliberale sensorium'. Berlant skitserer en ny affektiv samfundsklasse, prækariatet, som går på tværs af de økonomiske klasser; Cruel Optimism er med en henvisning til Occupy-bevægelsen blevet kaldt et affektivt portrxt af de 99\%.

\section{TEORI, TERAPI, POLITIK}

\section{Cruel Optimism og The Promise of Happi-} ness rummer både mere og mindre eksplicitte kritikker af, hvad man kan kalde neoliberale tidsåndsmarkører. Berlant og Ahmed taler om affektive strukturer af henholdsvis ond optimisme og pligten til glæde i terapiens tidsalder. Det er dette essays præmis, at vi i Danmark gennemgår en stærkt tiltagende neoliberalisering af samtlige tilværelsens aspekter. Neoliberalismen er blandt andet en effektiv afpolitisering af strukturelle og samfundsmæssige udfordringer, som medfører en stigende individualisering af kollektive problemer. Et eksempel kan være, at fagforeningerne er på retur samtidig med, at individuel coaching bliver mere og mere almindeligt. Det er op til den enkelte at levere ikke bare varen, men også et sundt sind og virkelyst. Den norske psykolog og filosof Ole Jacob Madsen har i bogen Den terapeutiske kultur (2010) beskrevet en række sammenhænge mellem neoliberal ideologi og psykologiseringen af stadigt flere sfærer i samfundslivet, fx forbrug, religion, virksomhedsledelse, selvhjælp, idræt, arbejdsliv, økonomi og politik. Når psykologiske tænkemåder og metoder vinder hævd, når psykologien og sindet bliver den primære horisont for den menneskelige tilværelse, sker det på bekostning af en særlig forståelse af forholdet mellem individuelle og samfundsmæssige forhold. Nina Trige Andersen skriver i Information om neoliberalismen, at den er en smilende magt, der ønsker, at du har det godt, og som sådan svær at kritisere (Trige Andersen 2013). Jens Malling har i en kronik samme sted stillet spørgsmålet: Er psykologien samfundets håndlanger (Malling 2013)? Han beskriver sindet som en resurse, der forvaltes på markedspræmisser. Vi skal have det godt, så vi kan gøre det bedre. Mange personer oplever stress, angst og depression og mange går i en form for terapi. De fleste former for psykologisk behandling er ekstremt fokuseret på individet og handler om at istandbringe og optimere dette. På den måde tager psykologien del i tendensen til at individualisere de samfundsmæssige problemer samtidig med, at den understøtter den tiltagende vækst- og effektiviseringsdogmatik i Danmark. Dette forhold sender alle på følelsesmæssigt overarbejde i et vanskeligt overskueligt sammensurium af arbejdsliv, privatliv, følelser, trivsel, politik og økonomi: Vi vil jo gerne have det godt.

Det er ikke sådan lige at stille sig uden for terapeutiske og psykologiske kulturer, foruden hvilke mange følelser, tanker og samtaler ville være umulige. Siden Foucault har meget feminisme og kønsforskning haft et akavet forhold til psykologien som institution og diskurs. Det er nødvendigt at problematisere psykologien som videnskab, statsautoriseret psykologisk praksis, vestlig selvhjælpskonsumerisme og coachingkulturer al den stund, at disse reducerer den menneskelige tilværelse til et snævert og apriorisk repertoire af psykologiske kausalitetsstrukturer, udvalgte traumekomponenter, succeskriterier og justeringer mod et bedre sind. Samtidig findes der i feminismen og i kønsforskningen en stærk tradition for at blande teori, terapi og politik. Tænk fx på kønsforskelsfeministernes ecriture feminine, bevidstgørelsesgrupper, basisgrupper, hvor gruppeterapi og samfundskritik konstituerer hinanden gensidigt og feministiske figurationer, som kan anskues som en form for kognitiv terapi.4. Sara Ahmed bidrager, som vi skal se, til denne tradition med en (re)lancering af figurationen 'Den feministiske Glædesdræber'. 


\section{FØLELSERNES POLITIK}

Ahmeds arbejde med følelser og affekt er bl.a. performativt anlagt. Det er således en central pointe at hun ikke definerer, hvad følelser og affekt er, men derimod undersøger, hvad følelser og affekt gør. Hun beskriver sit ærinde således:

I explore how emotions work to shape the 'surfaces' of individual and collective bodies. Bodies take the shape of the very contact they have with objects and others. My analysis proceeds by reading texts that circulate in the public domain, which work by aligning subjects with collectives by attributing 'others' as the 'source' of our feelings (Ahmed 2004: 1).

Således tager Ahmed del i teoretiseringerne af måden, hvorpå der produceres identitet og andethed. Når hun beskriver kroppe som følelsesformede, mener hun, at individer såvel som grupper orienterer sig efter følelser på den måde, at visse objekter eller praksisser kobles med visse følelser. Disse følelser er ikke immanente, men er nærmere bestemt en effekt af den kulturelle cirkulation af følelser. Det er Ahmeds ærinde at undersøge, hvordan objekter, materielle som immaterielle, ofte opfattes som årsag til følelser til trods for, at disse følelser snarere er en effekt af den følelsesmæssige orientering fra eller imod disse objekter.

I et queerfænomenologisk perspektiv har Ahmed formuleret at:

[...] the practices of thinking are not separated from the realm of the body but are implicated in the passion, emotions and materiality that are associated with lived embodiment.

(Koivunen 2010: 13).

I dette udsagn er den teoretiske pointe og opfordring at overskride krop/sind-hierarkiet - en både aldeles oplagt og, synes det, næsten uoverkommelig bevægelse post cogito. I The Cultural Politics of Emotion undersøger Ahmed, hvordan også det kulturelle spektrum af følelser og affekt etable- res omkring et socialt magt- og værdihierarki. Der findes høje og lave følelser, og i visse sammenhænge kan de rette følelser sanktionere en kulturel kapital, som er mere værdifuld end den sunde fornuft; de passende følelser kan facilitere et relativt højere stadie i evolutionistiske modernitetsdiskurser. Dette forudsætter selvfølgeligt en konstruktion og afmærkning af grupper eller individer med subalterne, inferiøre følelser. Mons Bissenbakker Frederiksen har, delvist inspireret af Sara Ahmed, skitseret følgende 'landkort' over følelsesladede stereotypiseringer: "modige mænd, hysteriske kvinder, aggressive lesbiske, forvirrede biseksuelle, sydlandske temperamenter, asiatisk ydmyghed, arabisk æresfølelse, sentimentale underklasser, følelseskolde overklassefamilier osv." (Bissenbakker Frederiksen \& Nebeling Petersen 2012: 5 ).

Ahmed skitserer to hovedtendenser i den humanistiske tænkning omkring følelser og affekt (Ahmed 2004: 8). Den ene kalder hun inside out-modellen, hvor følelser anskues som noget, der findes mere eller mindre dybt i kroppen og kommer til udtryk som en væsentlig del af det moderne essentialistiske subjekt. Med den anden model, outside in, beskriver hun de konstruktivistiske teorier, hvor følelser er kulturelt konstruerede og internaliseres i eller indskrives på den passive krop. Selvom følelser i det sidste perspektiv er et sociokulturelt anliggende, implicerer modellen, ligesom den essentialistiske, en statisk opfattelse af følelser som noget 'vi har'. I inside out-modellen tager følelser karakter af en form for sandhedsbærende autenticitet, hvor de i outside in-modellen er undertrykkende, magtmæssige og på sin vis falske. Ahmeds tilgang til følelser er imidlertid ikke et både-og, hvor følelser på samme tid er psykologiske immanente og socialt konstruerede:

Rather, I suggest that emotions are crucial to the very constitution of the psychic and the social as objects, a process which suggests 
that the 'objectivity' of the psychic and social is an effect rather than a cause. In other words, emotions are not 'in' the individual or the social, but produce the very surfaces and boundaries that allow the individual and the social to be delinated as if they are objects.

(Ahmed 2004: 10)

Ahmeds analyser er først og fremmest en undersøgelse af følelsernes sociopolitiske magt. Hun forskyder en opfattelse af følelser som sådan til en beskrivelse af objekter eller reifikationer af følelser, som cirkulerer og bevæger. Kroppe, individer og objekter refererer ikke blot til diskursive eller materielle organismer, men tænkes som inkommensurable bevægede og bevægelige affektive aflejringer. Følelser er desuden klistrende og visse objekter bliver overklistrede eller overmættede med visse følelser. Andre objekter, praksisser og domæner synes at være helt uden følelser eller bestemt af kontrollerede følelser. Det er i denne sammenhæng en vigtig pointe, at også størrelser som beherskelse, følelseskulde og kontenance er følelser, dvs. har at skaffe med affektive og følelsesmæssige investeringer og cirkulationer. Både det kølige overblik og den benhårde kalkule er følelsesmættede og bevægende størrelser - at det ikke føles sådan er netop en følelse.

Et centralt spørgsmål hos Ahmed lyder: hvorfor er sociale transformationer så svære at opnå? Hun undersøger specifikt følelserne smerte, had, frygt, afsky, skam, kærlighed - og queer følelser. Hvordan er disse følelser med til at skabe og opretholde magtasymmetrier mellem grupper, stater, individer? Jeg skal her give et eksempel fra kapitlet 'The Contingency of Pain'. Smerte opfattes i Vesten gerne som en privat og endda ensom følelse. Samtidig indgår smerten ofte i offentlige diskurser med det formål at vække til individuel, kollektiv eller national respons på uretfærdighed eller elendighed. Ahmed bruger et eksempel fra et brev som organisationen Christian Aid har sendt ud til sine bidragsydere. Brevet handler om minerydning i et krigsramt område. I sådanne sammenhænge vil det ofte være tilfældet, at smerten hos de mennesker, som oplever uretfærdighed, transformeres til tristhed eller medfølelse hos den eller de modtagere, som skal bevæges til handling. Denne transformation er kompleks. For det første belejres gruppen af uretfærdigt behandlede med en smerte, som bliver den måde, vi overhovedet kan tænke gruppen på. For det andet vil der, når 'deres' smerte bliver 'vores' smerte, ske en appropriering som forandrer, og måske endda neutraliserer, deres smerte til vores sorg eller tristhed:

It is not so much that we are 'with them' by feeling sad; the apparently shared negative feelings do not position the reader and victim in a relation of equivalence [...]. Rather, we feel sad about their suffering, an 'aboutness' that ensures that they remain object of 'our feeling' (Ahmed 2004: 21).

Hvilket altså udelukker, at 'de' kan være subjektet for de følelser, som vi tilskriver 'dem', og at 'de' overhovedet kan komme til udtryk og blive hørt på egne præmisser. På den måde kan den sociale cirkulation af smerte være med til at passivisere og underordne de individer, som oplever elendighed i forhold til de subjekter som synes at dele, men i grunden overtager smerten. Ahmed antyder, at denne struktur kan være et væsentligt element i den måde Vesten (the Western gaze) holder sig hævet over ikkevestlige stater eller grupper. Også i sammenhænge hvor det netop er vestlige foranstaltninger, som har kostet smerte i første omgang.

\section{VILJEN TIL LYKKE}

I The Promise of Happiness sætter Ahmed sit forehavende i forbindelse med en række nyere feministiske studier af følelser og affekt (Ahmed 2010: 13). Hun nævner værker af Berlant, Sedgwick, Cvetkovich, Brennan, 
Probyn, Ngai, Munt, Love og Woodward, og bemærker, at denne første runde af køns- og queerpolitisk affektteori ofte tager afsæt i 'dårlige' følelser. Som vi har set ovenfor med Ahmed som eksempel beskæftiger disse studier sig med den kulturelle cirkulation og forhandling af negativt mærkede følelser som fx had, frygt, angst, vrede, afsky - og skam! Følelser som i vestlig kultur klistrer sig til, eller slet og ret konstituerer, varianter af subalterne identitetskategorier og derfor kalder på kritiske strategier til genforhandlinger. I forlængelse heraf undersøger Ahmed i The Promise of Happiness en række socialpolitiske aspekter, som knytter sig til de positivt mærkede følelser glæde og lykke. Og al den stund det giver mening at tale om en bevægelse fra dårlige følelser til gode følelser - en vending i vendingen - kan vi altså sige, at den første runde af kønspolitisk og postkolonial affektteori dekonstruerer det dårlige ved dårlige følelser, og at den anden runde dekonstruerer det gode ved gode følelser. Berlants Cruel Optimism kan siges at være en del af sidstnævnte bestræbelse.

I indledningen til The Promise of Happiness stiller Ahmed spørgsmålet: "Why Happiness, Why Now?" (Ahmed 2010: 1). Hun giver tre begrundelser: to som handler om lykke og én som handler om ulykke. Den første begrundelse henter hun i, hvad hun kalder 'the new science of happiness'. I akademia findes der i dag en veletableret lykkevidenskab, hvis præmis det er, at lykken kan måles og analyseres hos individer såvel som hos grupper og stater. Et eksempel er de internationale indekser over respektive befolkningers lykkeniveau. Visse forskningsprojekter har til formål at demontere den forestillede kausalitetsstruktur økonomisk velstand lykke. På den måde bliver lykken en selvstændig økonomi, en resurse, som standardiseres og optræder paritetisk med internationale (vestlige) værdisystemer som fx BNP. Således udgør lykke et magtfuldt modernitets- og progressionsperformativ der, ligesom andre vestlige ud- præget individbaserede standarder, som fx IQ og Menneskerettighederne, bygger på specifikke, regionale, historiske konceptualiseringer. At måle lykke forudsætter en konstruktion af lykke, en lykkeapriori:

The science of happiness could be desribed as performative: by finding happiness in certain places, it generates those places as being what should be promoted as goods. Correlations are read as causalities, which then become the basis of promotion. (Ahmed 2010: 6)

Forskningen opererer med specifikke lykkeårsager, og for eksempel fungerer xgteskabet som en evidensbaseret lykkeindikator. Lykken måles der, hvor den forventes at være, dvs. inden for nogle snævre rammer, som privilegerer kernefamilien og vestlige fantasier om borgerlig frihed og demokratisk indflydelse. Selv når lykken meldes savnet: Ahmed refererer til en lykkekrise, som flankerer den økonomiske af slagsen - hvor der jo netop kan tales om to separate kriser, fordi videnskabelige standardiseringer har gjort lykken til en økonomi for sig. Men lykkekrisen fører ikke til en kritik eller genforhandling af standarderne for lykke. Ahmed skriver:

What is striking is that the crisis in happiness has not put social ideals into question and if anything has reinvigorated their hold over both psychic and political life. The demand for happiness is increasingly articulated as a demand to return to social ideals, as if what explains the crises of happines is not the failure of these ideals but our failure to follow them. (Ahmed 2010: 7)

Ahmeds anden begrundelse for at beskæftige sig med lykke er positiv psykologi. Eller nærmere bestemt den indflydelse på arbejds- og hverdagslivet, som varianter af positiv psykologi har haft gennem de seneste 20 år. Hvor lykkevidenskaben korrigerer økonomernes tendens til at fokusere på økonomisk vækst på bekostning af lykke, 
korrigerer positiv psykologi psykologiens tendens til at fokusere på negative følelsestilstande på bekostning af positive. Med den positive psykologi, som måske har gjort sig fortjent til neoliberalismens mest tilfredse smiley, er glædesimperativet absolut. Glæden instrumentaliseres og effektiviseres: At have det bedre, er at være bedre. I positiv psykologi er glæden, ifølge Ahmed, mindre en ret end en pligt. Til gengxld skal man virkeligt kæmpe for sin ret til ulykke.

I Danmark er dybdehermeneutiske, tilbageskuende terapiformer trådt i baggrunden til fordel for især den kognitive terapis fremadrettede ambition om at tilegne individet konstruktive tankestrukturer. Men også varianter af positiv psykologi er efterhånden velrepræsenteret $\mathrm{i}$ medier, politik, virksomheder, coaching, kommunal sundhedsfremme, markedsføring, hos jobkonsulenter osv.

Ahmeds ærinde er nu ikke at etablere et alternativt begreb om lykke, ej heller at bane vejen for en mindre dubiøs og mere autentisk lykke for de kritiske. "The question that guides the book is not so much "what is happiness?" but rather "what does happiness do?"'(Ahmed 2010: 2). I kapitlet 'Happy Objects' beskriver hun, hvordan individer og grupper gestalter den nærmeste sfære ved at orientere sig mod happy objects og ved at vende sig væk fra andre. What we like is what we are like. Eksempler på 'happy objects' kan være en klart defineret nationalitet, familien, xgteskab, demokrati, frihed, multikultur, sundhed, kontrol, tryghed, økologi osv. Proximitet til og associationer med lykkeobjekterne former, i fænomenologisk forstand, vores verdener. Ahmed problematiserer på den måde en elementær orientering efter dikotomien god/dårlig, hvor god og dårlig er effekter af affektive cirkulationer og investeringer frem for kvaliteter ved objektet: Objektet er jo, ifølge Ahmed, netop formet af følelsesmæssige investeringer.

Vejene til lykke er brolagt med normer for intimitet, kropsstørrelse, sundhed, ba- lance. Hvilke veje og rum findes når for eksempel det romantiske parforhold i ledtog med reproduktionsimperativet udgør et så basalt løfte om lykke, at et liv uden lige præcis det håb eller det løfte synes umuligt? Er tilværelsen indrettet efter specifikke happy objects, hvis affektionsværdi er så stor at et tab ville være et tab af selve livet? Det er ikke så vigtigt om lykkeobjekterne holder hvad de lover, for det gør de selvfølgeligt ikke, det vigtige er, at de virker som efterstræbelsesværdige former for liv og veje at gå. Hvad kan hente gyldighed som et godt liv? Hvilke gode liv har mulighed for at komme til udtryk og for hvem? Sara Ahmed skriver sig ind i traditionen af transgressionsfilosofier og opfordrer til at dræbe glæden: "To kill joy [...] is to open up a life, to make room for life, to make room for possibility, for chance“ (Ahmed 2010:20).

$\mathrm{Og}$ så er vi fremme ved bogens tredje begrundelse for at arbejde med lykke, den begrundelse som handler om ulykke. The Promise of Happiness er først og fremmest et arkiv for, og dokumentation af, ulykke. Bogen er tilegnet Audre Lorde ('The Uses of Anger: Women Responding to Racism') og de tre hovedkapitler hedder 'Feminist Killjoys', 'Unhappy Queers' og 'Melancholic Migrants'. Ahmed skriver:

Can we rewrite the history of happiness from the point of view of the wretch? If we listen to those who are cast as wretched, perhaps their wretchedness would no longer belong to them. The sorrow of the stranger might give us a different angle on happiness not because it teaches us what it is like or must be like to be a stranger, but because it might estrange us from the very happiness of the familiar (Ahmed 2010: 19).

Med The Promise of Happiness udfordrer Ahmed konventionerne for institutionelle arkivers hvad og hvordan. 5 Ahmed problematiserer en sjaldent udfordret konsensus, som findes på tværs af tankesystemer i den filosofiske tradition: At lykken er god. Det- 
te ærinde går hånd $\mathrm{i}$ hånd med et DIY-terapeutisk bevidstgørelsesprojekt: Det bevidste glædesdrab. Følelser som fx vrede har gennem tiderne været med til at diskvalificere visse erfaringer når kulturen dokumenteres. Hun videreformidler en gruppe historiske eksempler på ulykke, som dermed får et samlet udtryk og bliver en værdigfuld viden. En form for viden som ofte går tabt pga. den institutionelle bekvemmelighed. Hun beskæftiger sig specifikt med den diskursive og affektive kobling mellem feminisme og institutionelt/politisk ubehag, queers og ulykke, migranter og melankoli. Hvordan sikrer disse koblinger et underordningsforhold til størrelser som hvidhed, national identitet, fornuft og lykke? Jeg skal nedenfor give eksempler fra kapitlet 'Feminist Killjoys'.

\section{AT DRÆBE GLÆDEN}

I kapitlet 'Feminist Killjoys' beskriver Ahmed, hvordan feminisme er forbundet med negative følelser, mangel på humor, vrede og lignende, selve ordet er overmættet med unhappiness. I langt de fleste tænkelige situationer hersker en specifik forventning til en stemning, som er underforstået god, den gode stemning er et normativt krav, et solidaritetsimperativ. God stemning behøver i denne sammenhæng ikke at være forbundet med $\mathrm{fx}$ smil, der er også kriterier for god stemning og specifikke happy objects $\mathrm{i}$ forbindelse med en faglig diskussion af EU's toldmur og hungersnød. Men den gode stemning er, uanset hvordan den tager sig ud, på bekostning af en lang række alternative følelser og stemninger, og hvis en person bryder kontinuiteten i de følelsesmæssige cirkulationer, er det et problem for alle - og problemet er personen. Et eksempel kan være at, en feminist ødelægger den gode stemning ved at påpege, at en igangværende samfundsanalyse er kolonialistisk. Men selvom feministen peger på noget stærkt ubehageligt, som knytter sig til situationen og udgrænses af glædes- imperativet, vil han i situationen personificere problemet eller de følelser som udgrænses: Han udtrykker en indre vrede og modvillighed, som er en egenskab ved ham. Ahmed skriver:

My point here would be that feminists are read as being unhappy, such that situations of conflict, violence, and power are read as about the unhappiness of feminists, rather than being what feminists are unhappy about. (Ahmed 2010: 67).

Ahmed genbesøger den oprindeligt negative figur Glædesdræberen, og ved at dekonstruere glædesbegrebet fremskriver hun nye muligheder for at arbejde med og i nærheden af unhappiness. Med Glædesdræberen som figur opfordrer Ahmed til en større bevidsthed omkring magt/følelsesstrukturer:

We can recognize not only that we are not the cause of the unhappiness that has been attributed to us but also the effects of being attributed as the cause (Ahmed 2010: 87).

Det særlige ved Glædesdræberen er, at den - modsat feministiske figurationer i Braidotti-traditionen - ikke implicerer visionen om et bedre andet sted, da dette ville forudsætte et stabilt begreb om glæde og det gode. Men det betyder ikke, at Glædesdræberen er en bedrøvelig figur:

There is solidarity in recognizing our aliantation from happiness, even if we do not inhabit the same place (as we do not). There can even be joy in killing joy. And kill joy, we must and we do (Ibid.).

Mathias Danbolt har lavet et selvstudiekursus i queerfeministisk glædesdrab, som er tilgængeligt på modkraft.dk. Han skriver blandt andet:

Når folk bliver syge og ulykkelige af ikke at leve op til idealer om det perfekte æateskab 
eller effektiviseringen på jobbet, minder glædesdræberen os om, at løsningen måske ikke er at gå til behandling for at takle parforholdet eller at overleve stress på jobbet. Det, man virkelig behøver hjælp til, er at ændre på de normer og rammer, som organiserer kærligheden og arbejdslivet på måder, som begrænser vore mulighedsrum her i verden (Danbolt 2011).

\section{OND OPTIMISME}

Jeg runder af med en anbefaling af Lauren Berlants Cruel Optimism. Cruel Optimism er en både storslået og nedslående bog. Storslået fordi den giver en poetisk-teoretisk, flimrende, differerende og som sådan fyldestgørende karakteristik af det historiske nu $i$ et transnationalt perspektiv (USA og Europa). Og nedslående fordi den i et rørende deprimerende sprog beskriver en historisk samtid, som ikke bare er en krisetid, men en tid, hvor krisen er blevet den ordinære tilstand. Som tiden er, karakteriserer krisen ifølge Berlant ikke længere diskontinuitet eller det uventede, men derimod det ordinære. Hun skriver:

I am actually pretty lame at imagining a repaired world. What I provide best are depictions of what makes people stuck in the face of the ordinary pulsations of a fraying crisis (Berlant 2011: 159).

Cruel Optimism beskriver en tid, vores tid, hvor vestlige post war-idéer om det gode liv krakelerer og smuldrer uden at nye opstår. Efterkrigstidens socialdemokratiske/liberale løfter om politisk og social lighed, muligheden for opstigning, jobsikkerhed og holdbare intime relationer er på samme tid havarerede og effektive infrastrukturer som reproducerer livet på arbejdet, i intime relationer, i politik. Og det liberale løfte om et meritokrasi hvor intelligens, kompetence og ydelse er grundlaget for magtfordeling og social status, hvor kompetence og ydelse belønnes rimeligt, er i dag hverken troværdigt eller effektivt udfordret. Denne tilstand beskriver Berlant som et ideologisk og affektivt dødvande. Dødvandet beskriver hun blandt andet således:

[T] he impasse is a stretch of time in which one moves around with a sense that the world is at once intensely present and enigmatic, such that the activety of living demand both a wandering absorptive awareness and a hypervigilance that collects material that might help to clarify things, maintain one's sea legs, and coordinate the standard melodramatic crises with those processes that have not yet found their genre of event (Berlant 2011:4).

Men hvordan blive søstærk i et dødvande, i en inkohærent mos af depression, dissociation, pragmatisme, kynisme, optimisme, aktivisme? Det er bogens ærinde at undersøge, hvordan grupper og individer holder fast i livet i det neoliberale sensorium. Som titlen angiver, er det gennemgående greb i bogen den affektive struktur, som Berlant kalder ond optimisme:

A relation of cruel optimism exists when something you desire is actually an obstacle to your flourishing. It might involve food, or a kind of love; it might be a fantasy of the good life, or a political project [...] These kinds of optimistic relation are not inherently cruel. They become cruel only when the object that draws your attachment actively impedes the aim that brought you to it initially (Berlant 2011: 1).

Optimisme er hos Berlant en struktur, som findes i alle relationer og tilhørsforhold, og alle relationer er optimistiske, hvorfor optimisme ikke nødvendigvis behøver at føles optimistisk. Optimisme er det, som bringer individet ud af sig selv og ind i verden, det, som bevæger individet mod et objekt, et projekt, et koncept, en scene. Et begærsobjekt, eller det efterstræbte, beskriver Berlant som en klynge af løfter, og på den måde 
har hun mulighed for at forstå det inkoherente eller enigmatiske i vores hengivenhed til objektet. Hvis vi f.eks. læser et standardkriterium for det gode liv, xgteskabet, som en kompleks klynge af løfter, kan vi bedre forstå udholdenheden og tålmodigheden $\mathrm{i}$ vores optimisme. Hvorfor vi holder fast i den meget fantasifulde pakkeløsning af romantisk kærlighed, passioneret sex, juridiske privilegier og klausuler, reproduktion, økonomifællesskab, venskab, fortrolighed, husholdning osv., når nu denne pakkeløsning ofte viser sig at virke rigtigt dårligt. Med begrebet 'ond optimisme' ønsker Berlant at undersøge, hvad det er for affektive strukturer, som făr grupper og individer til at gå efter eller blive ved former for liv, der ikke virker. Vores stræben efter objekter, som er enten umulige - eller for mulige og giftige. Hun undersøger og undrer sig over en vedholdende hengivenhed til specifikke idéer om det gode liv i sammenhænge, hvor præcis disse idéer forhindrer individet $i$ at trives.

Berlant er informeret af blandt andet queer theory, marxisme og kritisk teori i frankfurtertraditionen, men bogen handler ikke om heteronormativitet, falsk bevidsthed, opium for folket, eller en folkemasse, som skal opdrages eller plejes med en injektion kultur. Ond optimisme er ikke en form for idioti, og det er ikke så simpelt, at det konventionelle valg er et let eller behageligt valg. Normer og konventioner er ikke det samme som fast grund under fødderne (hvilket for øvrigt bør være en helt central pointe for den, som vil bedrive normkritik). Berlant tegner konturerne af en ny klasse, et transnationalt prækariat. En klasse hvor opstigning og sikkerhed er skiftet ud med sidelæns bevægelse mellem periodiske parforhold, job, projekter, navne, seksualiteter og køn - sommetider over landegrænser og med 'foreløbigt' som pejlemærke. Prækariatet kan karakteriseres som en affektiv klasse, der findes på tværs af de økonomiske. Ikke blot fordi usikkerhed, stress, angst, depression findes på tværs, men også fordi præka- riatet specifikt opstår i en tid, hvor psykologien finder sammen med neoliberalismen $\mathrm{i}$ en frelles ambition om at optimere og udvikle sindet og følelseslivet, de menneskelige resurser.

\section{NoTER}

1. Eksempler herpå findes i Ann Cvetkovichs $D e$ pression: A Public Feeling (2012) og An Archive of Feelings (2003), hvor Cvetkovich i delvist terapeutisk øjemed tager afsæt i egne og bekendtes erfaringer med depression

2. Se fx de Mans Locke-læsning i 'The Epistemology of Metaphor' (1978).

3. Eve Sedgwick \& Adam Franks 'Shame in the Cybernetic Fold' og Brian Massumis 'The Autonomy of Affect' publiceres i 1995. Teksterne følges op af en intensiveret akademisk interesse for følelser og affekt, der af nogle omtales som den affektive vending.

4. Særligt biolog og videnskabsteoretiker Donna Haraway og filosof Rosi Braidotti har interesseret sig for figurationer som videnskabelig og politisk strategi. Braidotti er inspireret af Deleuzes fænomenologiske begreb om subjektets processuelle 'becoming', en fortløbende kropslig og affektiv tilblivelsesproces. Hos Braidotti er figurationen en politisk informeret alternativ subjektivitet. En figuration tager udgangspunkt i subjektets konkrete situation samtidig med, at den gestalter en vision for et andet sted, hvorved den viser vej ud af hegemoniske og konservative kønsparadigmer. Hos Haraway er figurationer fænomener, som befinder sig på grænsen mellem fakta og fiktion, mellem levet social realitet og fiktion. Haraways navnkundige Kyborg er netop en figuration som vederhæftigt og forførende trækker skråstregen ud af strukturer som virkelighed/fiktion og virtuel/materiel. (Se Lykke 2008: 45-48)

5. Ann Cvetkovichs An Archive of Feelings (2003), Judith Halberstams The Queer Art of Failure (2011) og Mathias Danbolts Ph.d-afhandling Touching History fra indeværende år er lignende eksempler på en gentænkning af hvad viden, historie og teori kan være. Værkerne handler om følelser, uvidenhed, glemsel, fejl, det usandsynlige, det meningsløse og desorienterede. 


\section{LITTERATUR}

- Ahmed, Sara (2004): The Cutlural Politics of Emotion. Routledge, New York.

- Ahmed, Sara (2010): The Promise of Happiness. Duke, London.

- Berlant, Lauren (2011): Cruel Optimism. Duke, London.

- Bissenbakker, Frederiksen Maja \& Michael Nebeling Petersen (red) (2012), i: affekt Varia nr. 9. - Danbolt, Mathias (2011): Queerfeministisk glædesdrab. Modkraft. 01/10/2013. Lokaliseret 19/08/2013 på http://modkraft.dk/node/ 16508 .

- Koivunen, Anu (2010): An Affective Turn?, i: Liljestöm \& Paasonen (red): Working with Affect in Feminist Readings. Routledge, New York.
- Lykke, Nina (2008): Kønsforskning. Forlaget Samfundslitteratur, Frederiksberg.

- Madsen, Ole Jacob (2010): Den terapeutiske kultur. Universitetsforlaget, Oslo.

· Malling, Jensen Jens (2013): Er psykologien sam-

fundets håndlanger? Dagbladet Information . 22/02/2013 Lokaliseret $11 / 11 / 2013$ på http://www.information.dk/452206.

- Trige Andersen, Nina (2013): Du kan kende den på smilet. Dagbladet Information. 01.03.2013.

Lokaliseret $11 / 11 / 2013$ på http://www.information.dk/453056.

Sanne Fræer Andersen

Cand.mag i dansk og kønsstudier 